\title{
Aktivitas Jamaah Majelis Taklim As-Syifa Walmahmudiyah Desa Sayati dalam Studi Interaksionisme Simbolik
}

\author{
Mamay Siti Maryam \\ FISIP Universitas Pasundan \\ Email Korespondensi: mamaysitimaryam2014@gmail.com
}

\begin{abstract}
The purpose of this article is to examine the activities of the Jamaah Majelis Taklim As-Syifa Walmahmudiyyah in Sayati Village in the study of symbolic interactionism. Using the paradigm of Interpretivism in the approach of symbolic interactionism theory refers to, George Herbet Mead. This research is within the discipline of qualitative research. The focus in this research is how to interpret mind-concept (Mind) self-concept and social interaction (Society) of Jamaah Majelis Taklim As-Syifa W almahmudiyah. The results showed that the recitation activity was a proselytizing activity that was beneficial for the thoughts, self, and social life of the congregation. Activities that have become a tradition of the As-Syifa Walmahmudiyah recitation congregational taklim assembly are recitation activities that have a unique character. The recitation activities beld were unusual, namely the time for the recitation from ba'da Isya at 20.00 until dawn. The implementation of the recitation has become a positive babit for the congregation and the surrounding community. The effectiveness of the recitation has a positive and negative impact on the performance of the As-Syifa Walmahmudiyyah majelis taklim congregation.
\end{abstract}

Keywords: Symbolic Interactionism, Da'wah, Majelis Taklim

\begin{abstract}
Abstrak
Tujuan dari artikel ini adalah untuk menguji aktivitas Jamaah Majelis Taklim As-Syifa Walmahmudiyyah Desa Sayati dalam studi interaksionisme simbolik. Menggunakan paradigma Interpretivisme dalam pendekatan teori interaksionisme simbolik mengacu kepada, George Herbet Mead. Penelitian ini berada dalam disiplin penelitian kualitatif. Fokus dalam penelitian ini adalah bagaimana pemaknaan konsep pemikiran (Mind) konsep diri (Self) dan interaksi sosial (Society) Jamaah Majelis Taklim As-Syifa Walmahmudiyah. Hasil penelitian menunjukan bahwa aktivitas pengajian merupakan aktivitas dakwah yang bermanfaat untuk pemikiran, diri, dan sosial jamaah. Aktivitas yang sudah menjadi tradisi jamaah pengajian majelis taklim AsSyifa Walmahmudiyah yaitu aktivitas pengajian yang memiliki karakter unik. Kegiatan pengajian yang diadakan tidak lazim, yaitu waktu pelaksanaan pengajian dari ba'da Isya pukul 20.00 sampai menjelang subuh. Pelaksanaan pengajian tersebut menjadi kebiasaan positif untuk jamaa'h dan masyarakat sekitar. Efektivitas pengajian tersebut memberi dampak positif dan negatif pada performa jamaa'h majelis taklim As-Syifa Walmahmudiyyah.
\end{abstract}

Kata Kunci: Interaksionisme Simbolik, Dakwah, Majelis Taklim 
Aktivitas Jama’ah Majlis Ta'lim As- Syifa Walmahmudiyah ...

\section{A. Pendahuluan}

Kegiatan dakwah sering dipahami sebagai sebuah kegiatan praktis, sama dengan tabligh (ceramah). Ceramah merupakan suatu kegiatan penyampaian ajaran Islam secara lisan yang dilakukan oleh para kiai di atas mimbar. Kegiatan tersebut dilakukan terbatas hanya di majelis taklim, masjid, dan mimbar keagamaan. Sementara di luar kegiatan itu belum dipahami sebagai dakwah. ${ }^{1}$ Hal tersebut tidak sepenuhnya keliru, tetapi harus dipahami pula bahwa dakwah tidak hanya ceramah tetapi setiap kegiatan yang bertujuan mengembangkan ajaran Islam, baik lisan, tulisan, maupun dengan tindakan.

Proses dakwah majelis taklim As-Syifa Walmahmudiyah memiliki karakter yang unik di bawah asuhan KH. Muhyidin Abdul Qadir. Jamaah pengajian sangat menghormati KH. Muhyiddin Abdul Qodir A. beserta kitabahnya. Menurut pengikutnya KH Muhyiddin ini tidak berkeinginan untuk terkenal di media dan lebih memilih berdakwah secara langsung bersama para jamaah. Kegiatan pengajian dilaksanakan dari pukul 20.00 sampai menjelang subuh yang hanya diikuti oleh jamaah majelis taklim As-Syifa. Fenomena pengajian ini jadi menarik untuk diteliti terkait dengan pemaknaan konsep pemikiran (Mind), konsep diri $\left(\right.$ Self), dan interaksi sosial (Society). ${ }^{2}$

Program khitabah ini menjadi kebiasaan (babitual) jamaahnya yang terlembagakan. Pelembagaan dalam perspektif Berger terjadi ketika semua kegiatan manusia mengalami proses pembiasaan (babitualisasi). Artinya tiap tindakan yang sering diulangi pada akhirnya akan menjadi suatu pola yang kemudian bisa direproduksi, dan dipahami oleh pelakunya sebagai pola yang dimaksudkan. ${ }^{3}$ Kegiatan majelis taklim As-Syifa telah menjadi sebuah kebiasaan yang terlembagakan sehingga para jamaah ini senantias hadir dalam tiap pengajian yang diadakan. Fenomena pengajian yang diadakan majelis taklim As-Syifa Walmahmudiyyah sangat menarik untuk diteliti terkait pemaknaan, konsep diri, dan interaksi sosial.

\section{B. Metode Penelitian}

Peneltian ini merupakan penelitian lapangan dengan maksud melibatkan diri dalam majelis taklim. Penelitian ini berada dalam disiplin penelitian kualitatif. berpendapat bahwa penelitian kualitatif adalah penelitian yang dimaksudkan untuk memahami fenomena tentang apa yang dialami oleh subjek penelitian, misalnya perilaku, persepsi, motivasi, tindakan dan lain-lain yang secara holistik dan dengan cara deskripsi dalam bentuk kata-

\footnotetext{
${ }^{1}$ Aep Kusnawan, "Dakwah Pada Masyarakat Teknologi," Ilmu Dakwah: Academic Journal for Homiletic Studies 10, no. 2 (2016).

${ }^{2}$ Riyadi Soeprapto, Inteaksionisme Simbolik (Malang: Averroes Press, 2002).

${ }^{3}$ Peter L. Berger and Thomas Luckmann, Tafsir Sosial Atas Kenyataan: Risalah Tentang Sosiologi Pengetabuan (Jakarta: LP3ES, 1990).
} 
kata dan bahasa pada suatu konteks khusus yang alamiah dan dengan memanfaatkan berbagai metode ilmiah. ${ }^{4}$ Secara metodologis, mind, self, society jamaah majelis taklim AsSyifa wal Mahmudiyyah yang diteliti dan ditelaah lebih dalam. Upaya yang dilakukan adalah membangun kerja sama dalam penyelenggaraan kegiatan pengajian untuk mengamati lebih mendalam unsur-unsur dalam diri jamaah dan dalam aktifitas jamaah di masyarakat.

Peneltian dengan pendekatan interaksionisme simbolik (Simbolic interactionisme theory) dipelopori oleh George Herbet Mead. ${ }^{5}$ Penelitian ini berada dalam disiplin penelitian kualitatif untuk memahami fenomena tentang apa yang dialami oleh subjek penelitian, misalnya perilaku, persepsi, motivasi, tindakan dan lain-lain yang secara holistik dan dengan cara deskripsi dalam bentuk kata-kata dan bahasa pada suatu konteks khusus yang alamiah dan dengan memanfaatkan berbagai metode ilmiah. Secara metodologis mind, self, society yang diteliti akan ditelaah lebih dalam tentang keberadaan jamaah di society-nya sebagai realitas komunikasi interaksi simbolik. Pendalaman dimaksud merupakan pengungkapan pemikiran jamaah yang tergabung dalam majelis taklim, diri jamaah setelah mengikuti pengajian, dan keberadaan jamaah di masyarakat. Penggunakaan interaksi simbolik dinilai efektif untuk mempengaruhi masyarakat dan memberikan kesempatan untuk menjalankan program organisasi. ${ }^{6}$

\section{Kajian tentang Teori Interaksionisme Simbolik}

Interaksi simbolik merupakan salah satu perspektif teori yang baru muncul setelah adanya teori aksi (action theory) yang dipelopori dan dikembangkan oleh Max Weber. Teori interaksi simbolik berkembang pertama kali di Universitas Chicago dan termasuk dalam pradigma definisi sosial. ${ }^{7}$ Tokoh utama dari teori ini antara lain John Dewey, dan C. H. Cooley, filsuf yang semula mengembangkan teori interaksi simbolik di universitas Michigan kemudian pindah ke Chicago dan banyak memberi pengaruh kepada W. I Thomas dan George Herbert Mead.

Self (Konsep diri) di dalam Al-Quran disebutkan, dan jiwa serta penyempurnaannya (ciptaannya), maka Allah mengilhamkan kepada jiwa itu (jalan) kefasikan dan ketakwaannya; sesungguhnya beruntunglah orang yang mensucikan jiwa itu, dan sesungguhnya merugilah orang yang mengotorinya (Q.S.91:7-10). Jadi manusia diberi pengetahuan tentang hal-hal yang positif dan negatif. Selanjutnya manusia mempunyai

\footnotetext{
${ }^{4}$ Lexy J. Moelong, Metodologi Penelitian Kualitatif (Bandung: PT. Remaja Rosdakarya, 2014).

${ }^{5}$ George Herbert Mead, Mind, Self, and Society: From the Standpoint of a Social Behaviorist (Chicago: The University of Chicago Press, 1934).

${ }^{6}$ Muhammad Luthfie et al., "Interaksi Simbolik Organisasi Masyarakat Dalam Pembangunan Desa," Informasi: Kajian Ilmu Kominikasi 47, no. 1 (2017).

${ }^{7}$ D Ritzer George and J Goodman, Teori Sosiologi Modern (Jakarta: Kencana, 2010).
} 
Aktivitas Jama’ah Majlis Ta'lim As- Syifa Walmahmudiyah ...

kebebasan untuk memilih jalan mana yang akan dia tempuh. Manusia punya potensi untuk menjadi jahat, sebagaimana ia juga punya potensi untuk menjadi baik.Agama (Islam) datang untuk mempertegas konsep diri yang positif bagi umat manusia. Manusia adalah makhluk yang termulia dari segala ciptaan Tuhan (Q.S.17:70) karenanya diberi amanah untuk memimpin dunia (Q.S.2:30). Walaupun demikian, manusia dapat pula jatuh ke derajat yang paling rendah, kecuali orang yang beriman dan beramal sholeh (Q.S.95:6).

Interaksionisme simbolik menjelaskan bahwa karakteristik dasar dari ide ini adalah suatu hubungan yang terjadi secara alami antara manusia dalam masyarakat dan hubungan masyarakat dengan individu. Hubungan yang terjadi antar individu berkembang melalui simbol-simbol yang mereka ciptakan. Interaksionisme simbolik juga berkaitan dengan gerak tubuh antara lain suara atau vocal, gerakan fisik dan ekspresi tubuh, yang kesemuanya itu mempunyai maksud dan disebut dengan "simbol".

Keterkaitan makna dan simbol dalam kajian Interaksionisme simbolik sangat erat, simbol dapat dipahami melalui bahasa yang diberi makna. Makna tidak melekat pada objek melainkan "dinegosiasikan melalui penggunaan bahasa". Negosiasi dimungkinkan karena manusia mampu menamai segala sesuatu, bukan hanya objek fisik, tindakan atau pristiwa, namun juga gagasan yang abstrak. Interaksionisme simbolik didasarkan pada ide-ide mengenai dan hubungan dengan masyarakat. Ada tiga tema besar dalam interaksionisme simbolik, yaitu teori interaksionisme simbolik berpegang bahwa individu membentuk makna melalui proses komunikasi karena makna tidak bersifat intrinsic terhadap apapun. Dibutuhkan konstruksi interpretif diantara orang-orang untuk menciptakan makna, bahkan tujuan interaksi menurut teori ini, adalah untuk menciptakan makna yang sama. Hal ini penting karena tanpa makna yang sama komunikasi akan menjadi sangat sulit atau bahkan tidak mungkin. Dengan kata lain makna adalah produk interaksi social, karena itu makna tidak melekat pada objek melainkan di negosiasikan melalui penggunaan bahasa. Negosiasi itu dimugkinkan karena manusia mampu menamai segala sesuatu bukan hanya objek fisik, tindakan, atau peristiwa namun juga gagasan yang abstrak. .

Mead, seperti juga choley menganggap bahwa konsep diri adalah suatu proses yang berasal dari interaksi sosial individu dengan orang lain. Salah satu teori yang dikemukakan choley berkaitan dengan konsep diri ini adalah theory looking-glass self. Menurutnya konsep diri individu secara signifikan ditentukan oleh apa yang ia pikirkan tentang pikiran orang lain mengenai dirinya, jadi menekankan pentingnya respons orang lain yang ditafsirkan

\footnotetext{
${ }^{8}$ Basrowi and Sukidin, Metode Penelitian Kualitatif Perspektif Mikro (Surabaya: Insan Cendekia, 2002).

${ }_{9}^{9}$ Deddy Mulyana, Ilmu Komunikasi: Suatu Pengantar (Bandung: Remaja Rosdakarya, 2008).
} 
secara subjektif sebagai sumber primer dara mengenai diri, ringkasnya sebagaimana dijelaskan apa yang diinternalisasikan sebagai milik individu berasal dari informasi yang ia terima dari orang lain.

Mead (1863-1931) dan Cooley (1846-1929) bersama kelompoknya menemukan bahwa individu-individu tersebut berinterkasi dengan menggunakan simbol-simbol, yang di dalamya berisi tanda-tanda, isyarat dan kata-kata. Pandangan interaksionisme simbolik adalah pandangan yang cukup unik, dan memilki sudut pandang yang berbeda dengan kebnyakan teori lain.Paham interksionisme simbolik memberikan banyak penekanan pada individu yang aktif dan kreatif ketimbang pendekatan-pendekatan toritis lainya. Mead mengklaim bahwa bahasa memungkinkan individu untuk menjadi mahluk yang sadar akan individualitas dan unsur kunci dalam proses ini dalah simbol.

Adapun konsep utama dalam teori interaksionisme simbolik menurut para teoritisi merupakan pengembangan dari teori mead yang ditulis dalam bukunya yang berjudul Mind, Self, and Society. Mind (pikiran) merupakan satu diantara tiga konsep penting dari interaksionisme simbolik Mead. Pikiran merupakan suatu percakapan terinternalisasikan atau implisist antara individu dengan dirinya sendiri dan menggunakan isyarat-isyarat. Lebih lanjut, konsep mind ialah kemampuan menemukan makna dan menunjukkanya kepada orang lain dan kendali ini dimungkinkan oleh bahasa. ${ }^{10}$ Karakteristik istimewa dari pikiran adalah kemampuan individu untuk memunculkan dalam dirinya sendiri tidak hanya satu respon saja, tetapi juga respon komunitas secara keseluruhan serta reaksi orang lain terhadap perilakunya.

Maka, kondisi yang dihasilkan adalah konsep diri yang mencakup kesadaran diri yang dipusatkan pada diri sebagai obyeknya. Isyarat sebagai simbol-simbol signifikan tersebut muncul pada individu yang membuat respons dengan penuh makna. Self didefinisikan sebagai kemampuan diri untuk merefleksikan diri sendiri dari perspektif orang lain. Wood menjelaskan bahwa "self as the ability to reflect on ourselves from the perspective of ofther". 11 Sementara West dan Turner menyebut sebagai "imagining how we look to another person"."

Society menurut Mead dijelaskan Wood bahwa "society is the web of social relationship bumans create and respond to" ${ }^{13}$ (merupakan jaringan hubungan sosial manusia dalam membuat dan menanggapi sesuatu). Sementara West dan Turner menjelaskan "defines

\footnotetext{
${ }^{10}$ Ibid.

${ }^{11}$ Julia T. Wood, Communication Theories in Action (California: Belmont, 2000).

12 Richard West and Lynn Turner, Pengantar Teori Komunikasi, Analisis Dan Aplikasi (Jakarta: Salemba Humanika, 2008).

13 Wood, Communication Theories in Action.
} 
Aktivitas Jama’ah Majlis Ta'lim As- Syifa Walmahmudiyah ...

society as the web of social relatonship that humans create." ${ }^{14}$ Mead menggunakan istilah masyarakat yang berarti proses sosial tanpa henti yang mendahului pikiran dan diri. Masyarakat penting perannya dalam membentuk pikiran dan diri. Di tingkat lain, menurut Mead, masyarakat mencerminkan sekumpulan tanggapan terorganisir yang diambil alih oleh individu dalam bentuk "aku". Menurut pengertian individual ini masyarakat mempengaruhi mereka, memberi mereka kemampuan melalui kritik diri untuk mengendalikan diri mereka sendiri.

Simbol yang dimaksudkan oleh West dan Turner adalah sebuah label arbriter atau representasi dari fenomena. Sedangkan label yang digunakan dapat bersifat ambigu, dan dapat berupa verbal dan non-verbal, dan dapat terjadi dalam komunikasi tatap muka maupun komunikasi dengan menggunakan media. Sejalan dengan pernyataan di atas, Mulyana menyatakan bahwa orang-orang yang berkomunikasi adalah komunikator yang aktif mengirimkan dan menafsirkan pesan, dan pada setiap saat mereka bertukar pesan verbal dan pesan non-verbal. ${ }^{15}$ Komunikasi adalah proses sosial dimana individu-individu menggunakan simbol-simbol untuk menciptakan dan menginterpretasikan makna dalam lingkungan mereka.

\section{Konsep Dasar Dakwah}

Dakwah Islam adalah suatu aktivitas untuk merubah situasi dari yang kurang baik kepada yang lebih baik, sehingga terbentuk sebuah tatanan kehidupan keluarga (usrab), kelompok sosial (jamaah), dan masyarakat (ummah) yang baik (khairu ummah), yaitu masyarakat yang terdiri dari individu-individu yang baik, beradab, dan berkualitas sesuai tuntunan Alquran dan Hadis

Memahami konsep gerakan dakwah secara komprehensif berarti memahami problematika dakwah yang sedang dijalani dan akan hadapi di masa-masa mendatang. Hal tersebut mencakup berbagai segi yang terkait dengan kehidupan manusia baik hubungannya dengan sesama makhluk Allah maupun yang terkait dengan hubungan manusia dengan sang Khalik. Syekh Ali Mahfud mendefinisikan dakwah adalah: ${ }^{16}$

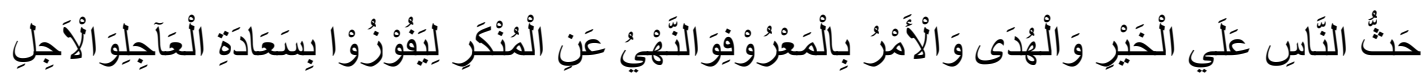

"Mengajak manusia kepada kebaikan dan petunjuk, dan menyuruh berbuat baik dan mencegah berbuat munkar untuk mencapai kebahagiaan dunia dan kebahagiaan akhirat".

${ }^{14}$ West and Turner, Pengantar Teori Komunikasi, Analisis Dan Aplikasi.

15 Mulyana, Ilmu Komunikasi: Suatu Pengantar.

${ }^{16}$ Munir, Metode Dakwah (Jakarta: Kencana, 2009). 
Dakwah dalam pengertian yang integralistik merupakan suatu proses yang berkesinambungan yang ditangani oleh para pengemban dakwah untuk mengubah sasaran dakwah agar bersedia masuk ke jalan Allah, dan secara bertahap menuju perikehidupan yang Islami. Suatu proses yang berkesinambungan adalah suatu proses yang bukan insidental atau kebetulan, melainkan benar-benar direncanakan, dilaksanakan, dan dievaluasi secara terus-menerus oleh para pengemban dakwah dalam rangka mengubah perilaku sasaran dakwah sesuai tujuan-tujuan yang dirumuskan. Secara etimologi, kata dakwah berasal dari bahasa 'Arab yakni: دعا يدعو ا دعاة/ دعوة. Jadi kata du'aa atau dakwah dalam isim masdar dari da'a yang keduanya mempunyai arti sama yaitu ajakan atau panggilan.

Subjek dakwah adalah yang melaksanakan tugas-tugas dakwah, orang itu disebut da’i atau muballigh. Dā’i merupakan orang yang melakukan dakwah, atau dapat diartikan sebagai orang yang menyampaikan pesan dakwah kepada orang lain (mad'ū). Dā’i bisa secara individual, kelompok, organisasi atau lembaga yang dipanggil unruk melakukan tindakan dakwah. Dā’i memiliki posisi yang sentral dalam dakwah, sehingga dā’i harus memiliki citra atau image yang baik dalam masyarakat. Pemahaman ini diperoleh dari makna dakwah yang berarti mengajak, berdoa, mengadu, memanggil, meminta dan mengundang. ${ }^{17}$ Lebih lanjut, dakwah berupaya untuk menumbuhkan kesadaran dari dalam diri mad'u, yaitu suatu kesadaran yang memungkinkan mad'u mempunyai persepsi, pemahaman dan kesadaran yang cukup sempurna tentang Islam sebagai sumber nilai dalam hidupnya, dan juga dapat menumbuhkan kekuatan dan kemauan dalam dirinya untuk menginternalisasikan, merealisasikan dan mengaktualisasikan nilai-nilai Islam tersebut dalam kehidupannya sehari-hari.

Aktivitas berdakwah dapat dilakukan dengan berbagai macam cara atau metode sesuai dengan kekhasan da’i dan masyarakat. Metode dakwah adalah cara-cara menyampaikan pesan kepada objek dakwah, baik itu kepada individu, kelompok maupun masyarakat agar pesan-pesan tersebut mudah diterima, diyakini dan diamalkan. Metode dakwah yang paling utama ialah melalui keteladanan dan mavidhob hasanah, namun tidak menutup kemungkinan menggunakan metode lain sesuai karakteristik masyarakat dan juga perkembangan zaman.

Materi dakwah berisi pesan-pesan ajaran Islam agar diketahui, dipahami, dan diamalkan sebagai pedoman hidup. ${ }^{18}$ Materi tersebut diberikan sesuai dengan tujuan

${ }^{17}$ Moh. Ali Aziz, Ilmu Dakwah (Jakarta: Kencana, 2004).

${ }^{18}$ Ibid. 
Aktivitas Jama’ah Majlis Ta'lim As- Syifa Walmahmudiyah ...

dakwah Islam yang mengacu kepada kitab Al-Quran sebagai kitab dakwah utama. Tujuan tersebut yakni mengeluarkan manusia dari kegelapan hidup kepada cahaya yang terang ( QS. 2: 257). Upaya menegakan fitrah insaniyah (QS. Al-Rum: 30), menegaskan tugas ibadah manusia sebagai hamba Allah (QS. 2: 21), serta upaya menegakan aktualisasi pemeliharaan agama, jiwa, akal, generasi dan sarana hidup.

\section{E. Pembahasan}

\section{Pemaknaan jamaah (mind) terhadap pengajian KH Muhyidin}

Mind (pikiran) merupakan satu diantara tiga konsep penting dari interaksionisme simbolik Mead. ${ }^{19}$ Kegiatan dakwah yang diadakan dari jam 20.00 sampai 03.00 dimaknai oleh para jamaah merupakan waktu yang tepat untuk pengajian dengan alasan waktu yang disediakan merupakan pilihan dari guru yang mereka yaitu KH. Muhyidin Abdul Qodir. Alasan kedua karena malam hari merupakan waktu yang panjang sehingga acara yang dilaksanakan dapat berjalan dengan maksimal.

KH Muhyidin dan jamaahnya dalam rangka aktivitas dakwahnya menggunakan simbol-simbol. Simbol yang digunakan diantaranya adalah gamis putih, sorban, gaya bicaranya yang sederhana, iringan gendang yang merupakan simbol ketika penceramah berhenti berbicara. Dua yang paling utama dalam kegiatan dakwah yaitu sikap mental yang positif yang harus dipegang oleh juru dakwah dan penyampaian informasi dakwah sebaikbaiknya. ${ }^{20}$ Dengan bahasa lain setiap muslim berkewajiban untuk berdakwah. Perintah ini ditulis dalam Alquran yang memerintahkan mereka untuk berbuat makruf dan mencegah kepada yang munkar agar mereka mendapat kebahagiaan di dunia dan akhirat.

Teori ketiga Blummer menyatakan bahwa interpretasi individu mengenai simbol dibentuk oleh pemikirannya sendiri atau "individual's interpretation of symbols is modified by his or her own thought processes". Dua yang paling utama dalam kegiatan dakwah yaitu sikap mental yang positif yang harus dipegang oleh juru dakwah dan penyampaian informasi dakwah sebaik-baiknya. ${ }^{21}$ Mind dikaji dengan pendekatan intervetif, membutuhkan peran psikologi dakwah dalam aktifitas dakwah. Kegiatan dakwah dapat berlangsung dengan lancar dan berhasil dengan baik diperlukan pengetahuan tentang psikologi dakwah. Karena kegiatan dakwah pada dasarnya adalah kegiatan penyampaian informasi dari seseorang kepada orang lain. Maka perlu mengkaji prinsip dasar psikologi komunikasi, berhasil atau tidaknya suatu kegiatan dakwah sangat ditentukan oleh sikap mental pengetahuan juru dakwah.

${ }^{19}$ Mulyana, Ilmu Komunikasi: Suatu Pengantar.

${ }_{20}$ Ancok Djamaludin and Fuad Nashori Suroso, Psikologi Islam (Solusi Islam Atas Problem-Problem Psikologi) (Yogyakarta: Pustaka Pelajar, 1995).

21 Ibid. 
Dengan memperhatikan faktor-faktor perkembangan psikologis beserta ciri-cirinya, maka pesan dakwah yang disampaikan oleh juru dakwah akan dapat meresap dan diterima dalam pribadi sasarannya dan kemudian diamalkannya kepada perasaan yang tulus tanpa adanya ganjalan karena hal tersebut dapat menyentuh dan memuaskan kehidupan rohaninya. Disinilah letak titik berat strategi-strategi dakwah yang sebenarnya yaitu menerima pesan dakwah dengan ikhlas sekaligus mempraktekkannya. Psikologi dakwah merupakan kesatuan analisis terhadap tingkah laku manusia melalui pendekatan psikologi dan dakwah geologis yang terdisipliner. Sebagai pembahasan yang mempedomani psikologi, maka psikologi dakwah ini termasuk di dalam ruang lingkup pembicaraan psikologi teoritis khusus, dan juga dalam psikologi praktis aplikaitif. ${ }^{22}$

\section{Konsep Diri (Self) Jamaah Pengajian Majelis Taklim Asyifa Walmahmudiyah}

Konsep diri (self) Jamaah membentuk konsep diri mereka masing - masing dengan kesadaran mereka mengikuti kegiatan dakwah, mereka mengangap kegiatan dakwah memperkuat dirinya untuk senantiasa menjadi yang terdepan dalam membela Rasulullah Saw. Proses ini disebut dengan pemenuhan diri atau pengharapan akan diri yang menyebabkan seseorang untuk berperilalu sedemikian rupa sehingga harapannya terwujud. Konsep diri yang berkembang pada jamaah As-Syifa Walmamudiah suatu proses yang berasal dari interaksi sosial individu dengan orang lain. Konsep diri ini juga membentuk konsep diri masyarakat.

Self (konsep diri) menurut teori interaksionisme simbolik memberikan motif penting untuk perilaku dan pemikiran bahwa nilai, keyakinan, perasaan, penilaian mengenai diri mempengaruhi perilaku. Mead berpendapat bahwa karena manusia mempunyai diri, mereka memiliki mekanisme untuk berinteraksi dengan diri, mekanisme ini digunakan untuk berinteraksi dengan dirinya sendiri, mekanisme ini digunakan untuk menuntun prilaku dan sikap. Self sebagi kemampuan diri untuk merefleksikan diri kita sendiri dari perspektif orang lain.

Konsep diri jamaah teruji dari pernyataannya dan konsistensi dalam mengikuti pengajian. Pengajian yang diadakan malam hari sampai menjelang subuh ini lebih baik daripada tahajud. Coba lihat ketika orang tahajud hanya sebatas sholat saja lalu tidur lagi, tapi kalau pengajian ini tidak tidur semalaman dan terus bersholawat jadi bisa ibadah semalaman suntuk tanpa tidur. ${ }^{23}$ Pernyataan seperti itu keluar bukan hanya secara kebetulan dari dirinya saja, namun pernyataan ini didasarkan dari lingkungan jamaah.

\footnotetext{
${ }^{22}$ Jamaluddin Kafie, Psikologi Dakwah: Bidang Studi Dan Bahan Acuan (Surabaya: Penerbit Indah, 1993).

${ }^{23}$ Rahman, "Wawancara," 2020.
} 
Aktivitas Jama’ah Majlis Ta'lim As- Syifa Walmahmudiyah ...

Teori Interaksionisme simbolik ini dalam menerangkan diri masih relevan dengan zaman ini sebagaimana penjelasan tentang Self yaitu kemampuan diri untuk merefleksikan diri kita sendiri dari perspektif orang lain. Jamaah majelis taklim As-Syifa ini dalam mereflesikan diri mereka dari persefektif orang lain sangat bergantung pada lingkungannya. Pernyataan pengajian lebih baik daripada tahajud adalah pernyataan yang kurang tepat, tahajud dan pengajian tidak bisa disandingkan. Sudah diketahui bahwa tahajud adalah amalan para Nabi, bahkan sebelum sholat lima waktu diwajibkan. Tahajud atau sholat qiyamullail yang dilaksanakan. Sholat tahajud pula yang dilaksanakan oleh Rasulullah, di sini terjadi kesenjangan atau masalah dimana di satu sisi mengagungkan Rasulullah dengan acara pengajian semalam suntuk, namun di sisi lain anjuran dari Rasulullah seperti sholat qiyamulail justru dikesampingkan. Sebagai kaum muslimin yang mengagumi Rasulullah tentu harus mencontoh dan melaksanakan amalan ibadah yang dianjurkan.

Konsep diri jamaah majelis taklim As-Syifa Walmahmudiyah ini secara umum sama, namun konsep diri ini yang bertujuan membentuk keshalehan secara menyeluruh tidak terealisasikan dengan baik dalam diri masing-masing jamaah. Para jamaah meyakini acara ini bertujuan untuk mencari ridho Allah, bekal untuk mendapatkan syafaat di yaumil akhir. Acara ini untuk memohon keberkahan karena barang siapa yang mengagungkan Nabi berarti mengagungkan Allah, ditambah yakin karena ada guru yang membimbing yaitu KH. Muhyidin. Tujuan dari acara ini adalah untuk merekrut para pemuda yang berkeliaran di malam hari, yang tadinya mabuk-mabukan, kelompok anak punk, dan bekerjasama dengan RW untuk lebih dekat dengan majelis taklim ini. ${ }^{24}$

Konsep diri di dalam Al-Quran disebutkan, "dan jiwa serta penyempurnaannya (ciptaannya), maka Allah mengilhamkan kepada jiwa itu (jalan) kefasikan dan ketakwaannya; sesungguhnya beruntunglah orang yang mensucikan jiwa itu, dan sesungguhnya merugilah orang yang mengotorinya" (Q.S.91:7-10). Jadi manusia diberi pengetahuan tentang hal-hal yang positif dan negatif. Selanjutnya manusia mempunyai kebebasan untuk memilih jalan mana yang akan dia tempuh. Manusia punya potensi untuk menjadi jahat, sebagaimana ia juga punya potensi untuk menjadi baik.Agama (Islam) datang untuk mempertegas konsep diri yang positif bagi umat manusia. Manusia adalah makhluk yang termulia dari segala ciptaan Tuhan (Q.S.17:70). Karena itu, ia diberi amanah untuk memimpin dunia ini (Q.S.2:30). Walaupun demikian, manusia dapat pula jatuh kederjat yang paling rendah, kecuali orang-orang yang beriman dan beramal sholeh (Q.S.95:6).

Konsep diri jamaah majelis taklim As-Syifa memandang Rasulullah sosok yang agung,

${ }^{24}$ Nanang, "Wawancara," 2020. 
namun ada jamaah yang lupa akan ibadah Rasulullah yaitu shalat tahajud. Jamaah membandingkan shalat tahajud dengan pengajian, padahal keduanya adalah ibadah yang dilakukan oleh orang yang mereka agungkan (Nabi Muhammad Saw) yang seharusnya bukan dibandingkan namun menjadi konsep diri yang mengakar sehingga menanamkan kesolehan yang menyeluruh.

Tidak sedikit ayat-ayat yang terdapat dalam Al-Quran yang menyebut kata iman dan diiringi oleh kata amal (allaz̧ina amanu wa amilus-sholihat), ini bukan saja menunjukkan eratnya hubungan di antara keduanya, tetapi juga menunjukkan betapa pentingnya iman dan amal tersebut. Dengan demikian maka nilai seseorang ditentukan oleh iman dan amalnya juga. Sesungguhnya Allah tidak akan melihat kepada bentuk (rupa) kamu, tidak pula keturunan (bangsa) kamu, tidak juga harta tetapi melihat kepada hati dan amal perbuatan kamu (H.R Thabrani). Semua manusia adalah sama di sisi Allah, yang lebih mulia hanyalah orang yang paling bertakwa (Q.S.49:13).

\section{Pola Interaksi diantara Jamaah Majelis Taklim Asyifa Walmahmudiyah}

Society atau hubungan sosial baik antara anggota jamaah maupun dengan masyarakat sekitar kurang harmonis. Sebagai anggota dari jamaah ini mereka sangat dekat, kerjasama dan komunikasi terjalin sangat baik, namun di lingkungan masyarakat sendiri terjadi beberapa perbedaan pendapat. Masyarakat di lingkungan ini ada yang suka dan ada yang tidak suka dengan kegiatan tersebut. "Sehari-hari kami tidak sholat di masjid, bukan berarti tidak mau, tapi ketua DKM dan pengurusnya berbeda pemikiran dengan kami, walaupun hanya sholat jumat saja kami ke masjid". ${ }^{25}$ Sekelompok manusia dapat dikatakan sebagai sebuah masyarakat apabila memiliki pemikiran, perasaan, serta sistem/aturan yang sama. Dengan kesamaan-kesamaan tersebut, manusia kemudian berinteraksi sesama mereka berdasarkan kemaslahatan.

Society dalam hubungan bermuamalah dengan para tokoh di sekitar kurang harmonis sehingga menimbulkan kesan yang kurang baik. Kegiatan yang dilakukan anak muda untuk mengikuti pengajian sampai menjelang subuh memang dianggap baik oleh masyarakat. Akantetapi masyarakat juga berharap mereka bisa bersama-sama dengan pengurus masjid untuk kegiatan lainnya. Hubungan bermasyarakat harus lebih solid bukan malah berseteru hanya karena sedikit perbedaan. "Acara yang diadakanya baik, tapi sebelum acara mereka suka latihan sholawatan, waktu untuk latihanya sampai larut malam itu mengganggu tetangga, cobalah diperbaiki lagi jadwal latihanya". ${ }^{26}$ Kegiatan dakwah itu memang baik,

\footnotetext{
25 Zaki, "Wawancara," 2020.

${ }^{26}$ Salim Wahyudi, "Wawancara," 2020.
} 
Aktivitas Jama’ah Majlis Ta'lim As- Syifa Walmahmudiyah ...

tapi harus tertanam pada jama'aahnya jangan sampai kegiatan dakwahnya rajin tetapi sholatnya ditinggalkan. Semua kaum muslimin seharusnya berkewajiban memakmurkan masjid, tapi karena perbedaan pendapat malah membuat masjid menjadi sepi.

Perubahaan sosial di tengah masyarakat menjadi positif dengan adanya pengajian ini. Masyarakat pada awalnya mempunyai kebiasaan buruk seperti pesta dangdut sambil saweran dan minuman keras. Setelah jamaah itu datang dengan acara dari ba'da Isa sampai menjelang subuh mampu mengubah masyarakat sehingga banyak yang mengikuti pengajian. Masyarakat merupakan kumpulan orang-orang yang tentu memiliki kebiasaan dan pemikiran yang berbeda, dalam pembahasan society ini terdapat beberapa permaslahan, di satu sisi kegiatan yang dilakukan adalah kegiatan yang positif, namun keberadaan jamaah majelis taklim As-Syifa ini bagi masyarakat setempat dirasakan biasa saja bahkan masyarakat ada yang tidak suka, karena menurut sebagian masyarakat banyak mengganggunya daripada manfaatnya.

Pengajian yang sampai menjelang subuh sehingga terlewat sholat subuh itu menjadi berlawanan dengan pemaknaan dan diri jamaah. Ummatan Wâhidatan, yakni masyarakat universal dan kosmopolitan yang menghargai perbedaan (pluralisme) dan menjadikannya sebagai peluang yang diarahkan pada kompetisi ke arah kebajikan. Ummatan Qâimatan, yaitu masyarakat yang tetap konsisten memperjuangkan kebenaran dan keadilan di bawah bayang-bayang kebejatan moral para penguasa. Ini diungkapkan dalam Alquran surat Âli Imrân (3) ayat 113-114 sehingga umat muslim harus menjalankan dan memperjuangkan apa yang diajarkan dalam Alquran.

\section{F. Simpulan}

Berdasarkan hasil penelitian dapat disimpulkan bahwa terdapat dua pandangan terhadap pola interaksi jamaah majelis taklim Asyifa Walmahmudiah, yaitu pandangan baik dan pandangan kurang baik. Pandangan baik yaitu jamaah ini terdiri dari orang-orang shaleh, bekerja sama, saling membantu untuk mensukseskan kegiatan dakwahnya. Kegiatan dakwah yang dilakukan berdampak baik untuk meminimalisir kegiatan kurang baik masyarakat setempat yakni dangdutan yang diiringi sawer dan mabuk-mabukan. Pandangan kurang baiknya, jamaah ini tidak dapat bekerjasama dengan dewan kemakmuran masjid (DKM) dan dengan para pengurus masjid tempat mereka tinggal. Berselisih paham membuat jamaah ini tidak melaksanakan sholat di masjid kecuali sholat juma'at. Inilah yang membuat pandangan masyarakat setempat menilai jamaah ini kurang menyeluruh dalam melaksanakan ajaran Islam. 


\section{Daftar Pustaka}

Aziz, Moh. Ali. Ilmu Dakwah. Jakarta: Kencana, 2004.

Basrowi, and Sukidin. Metode Penelitian Kualitatif Perspektif Mikro. Surabaya: Insan Cendekia, 2002.

Berger, Peter L., and Thomas Luckmann. Tafsir Sosial Atas Kenyataan: Risalab Tentang Sosiologi Pengetahuan. Jakarta: LP3ES, 1990.

Djamaludin, Ancok, and Fuad Nashori Suroso. Psikologi Islam (Solusi Islam Atas ProblemProblem Psikologi). Yogyakarta: Pustaka Pelajar, 1995.

Kafie, Jamaluddin. Psikologi Dakwab: Bidang Studi Dan Bahan Acuan. Surabaya: Penerbit Indah, 1993.

Kusnawan, Aep. "Dakwah Pada Masyarakat Teknologi." Ilmu Dakwah: Academic Journal for Homiletic Studies 10, no. 2 (2016).

Luthfie, Muhammad, Aida Viyala S Hubeis, Amiruddin Saleh, and Basita Ginting. "Interaksi Simbolik Organisasi Masyarakat Dalam Pembangunan Desa.” Informasi: Kajian Ilmu Kominikasi 47, no. 1 (2017).

Mead, George Herbert. Mind, Self, and Society: From the Standpoint of a Social Bebaviorist. Chicago: The University of Chicago Press, 1934.

Moelong, Lexy J. Metodologi Penelitian Kualitatif. Bandung: PT. Remaja Rosdakarya, 2014.

Mulyana, Deddy. Ilmu Komunikasi: Suatu Pengantar. Bandung: Remaja Rosdakarya, 2008.

Munir. Metode Dakwah. Jakarta: Kencana, 2009.

Nanang. "Wawancara," 2020.

Rahman. "Wawancara," 2020.

Ritzer George, D, and J Goodman. Teori Sosiologi Modern. Jakarta: Kencana, 2010.

Soeprapto, Riyadi. Inteaksionisme Simbolik. Malang: Averroes Press, 2002.

Wahyudi, Salim. "Wawancara," 2020.

West, Richard, and Lynn Turner. Pengantar Teori Komunikasi, Analisis Dan Aplikasi. Jakarta: Salemba Humanika, 2008.

Wood, Julia T. Communication Theories in Action. California: Belmont, 2000.

Zaki. "Wawancara," 2020. 
Aktivitas Jama'ah Majlis Ta'lim As- Syifa Walmahmudiyah ... 